Kong. Res. J. 2(2) : 60-61, 2015

ISSN 2349-2694

Kongunadu Arts and Science College, Coimbatore.

\title{
STUDY OF ORCHIDS DIVERSITY IN KOLLI HILLS, EASTERN GHATS, TAMIL NADU.
}

\author{
Rajarajeshwari, J*. and K. Nandakumar \\ PG and Research Department of Botany, Kandaswamy Kandar's College, Namakkal \\ *E.mail: privacy_raji@yahoo.co.in
}

\section{ABSTRACT}

The present paper deals with the diversity of orchids in kolli hills. In past years above 70 sps of Orchids distributed in kolli hills.(Karuppasamy et al., 2009). But currently 42 species are dominant over in this area. Among this habitats Epiphytic 52.38\% of Orchids contributed higher percentage followedby Terrestrial $42.86 \%$ and Lithophytic 4.76\%. Epiphytic Orchids are highly trophical and sub-trophical in distributed. Most of orchids like Eris, bulbophyllum keitense and Habineria are in extinct stage because of deforestation and utilization. In this stage conservation of Orchids is most important. The collected orchids are listed below according to their alphabetical order.

Keyword: Kolli hills, Orchids, distribution, deforestation, conservation.

\section{INTRODUCTION}

Orchid are the second largest group of flowering plant comprising about 788genera and 18,500 sps (Mabberley, 1997) they are distributed throughout the world, except the hot deserts and Antartica. In India they are represented by 190 genera and 1300 species. Based on their varying habits, Orchids are classified into Saprophytic, Terrestrials, Epiphytic and Lithophytic. The number of flowering plant taxa represented approximately in the Eastern Ghats to be about 3500.

While, it is generally accepted today that the conservation of all biodiversity should be the goal. Understanding the natural distribution of plants (floristic studies) is central to conserving biodiversity and managing ecosystems for long term viability and sustainability (Ali Mohammad Asadi, 2009).

In this prospective the study was conceived to understand the Orchid diversity of Kolli hills of Eastern Ghats.

\section{MATERIALS AND METHODS}

\subsection{Study area}

Kolli hills of Eastern Ghats lies in Namakkal district, tamilnadu is well known for its biological diversity. It has a total area of $490 \mathrm{~km}^{2}$.kolli hills flanked Namakkal taluk on the South, and South West. Rasipuram on the North and North East, Attur taluk is on the north east and Trichy district in the east. The altitude ranges from $400-1400 \mathrm{~m}$ rising to $1450 \mathrm{~m}$ Kuzhivalavu. $\left(11^{0} 10^{\prime}-11^{0} 27^{\prime} \mathrm{N}\right.$ and $78^{0} 18^{\prime}-$ $78030^{\prime}$ E.) the vegetation of Kolli hills is of mixed deciduous and evergreen types. The temperature ranges from $12^{\circ} \mathrm{C}-25^{\circ} \mathrm{C}$ and the annual rainfall from 1200 to $1400 \mathrm{~mm}$. Kolli hills is called as Chaturagiri or Square hills contain of high raising peaks and ravines slopes are quite steep forming several narrow and deep valleys and in some places rising abruptly from plains and generally steep near ridges. So that the edge of the plateau is sharply defined. Along the slopes and foot hills the soil is red sandyloam with rich in limestone and elements. Many of the areas of the hill are under mining for bauxite.

Kolli hills drained by two rivers, Vasisthanadhi and Swetanadhi. Swetanadhi originates from kolli hills and drains the Northern side of Salem district. Vasisthanadhi is called as Pearer and originates from Aranuttmalai, turns eastwards and which is an irrigation resource to Attur taluk.

\subsection{Field survey}

Periodical field survey was conducted during the year 2011-2014 for collection of Orchids. Frequent field trips were made in all flowering seasons in those years. The study was based on field work and taxonomical examination of orchids.

\section{RESULT AND DISCUSSION}

In kolli hills, Orchids are beings to appear from $500 \mathrm{~m}$ elevation onwards. Apart from climatic condition altitude play vital role for the distribution of Orchids. In the present study about 42 species belonging to 28 genus (Table 1) Orchids were collected and identified. During the course of survey maximum of Orchids were recorded in Kuzhivazhavu shola followed by Nachiyar kovil. 
Table 1. Enumeration of Orchids in Kolli hills.

\begin{tabular}{|c|c|c|c|c|}
\hline S.No. & Botanical name & Habitat & Types of vegetation & Floral period \\
\hline 1 & Acampe praemorsa (Roxb.) Blatt. & Epiphyte & MD,SEG & Jan-Mar \\
\hline 2 & Acanthephippium bicolor Lindl. & Terrestrial & Shola & Apr-June \\
\hline 3 & Arides ringens (Lindl.)Fishcer & Epiphytic & EG, SEG & June-July \\
\hline 4 & Anoectochilus elatus Lindl. & Terrestrial & EG, Shola & June-Sept \\
\hline 5 & Bulbophyllum kaitense Reichb.f. & Epiphytic & SEG-MD & Sept \\
\hline 6 & Bulbophyllum neilgherrense Wight & Epiphyte & EG-SEG & Feb-Mar \\
\hline 7 & Calanthe triplicata (Willem) Ames & Terrestrial & EG,SEG,Shola & July-Sept \\
\hline 8 & Coelogyne breviscapa Lindl. & Epiphytic & $\mathrm{EG}$ & Feb-Mar \\
\hline 9 & Coelgyne odorratissima & Terrestrial & EG,Shola & Feb-Mar \\
\hline 10 & Chysoglossum maculatum (Thw.) Hook.f. & Terrestrial & Shola & Feb-Mar, Dec-Jan \\
\hline 11 & Dendrobium aquem Lindl. & Epiphytic & $\mathrm{EG}, \mathrm{SEG}$ & Sept-Oct \\
\hline 12 & Dendrobium herbaceum Lindl. & Epiphyte & EG & Mar-July \\
\hline 13 & Dendrobium heterocarpum Well. ex Lindl & Epiphyte & EG,Shola & Apr-June \\
\hline 14 & Diplocentrum recurvum Lindl. & Epiphyte & EG & May-June, July-Aug \\
\hline 15 & Disperis neilgherrensis Wight. & Terrestria & Shila & Aug-Sept \\
\hline 16 & Eria pauciflora Wight & Epiphyte & EG & Aug-Sept \\
\hline 17 & Eria polystachya A.Rich & Terrestrial & Shola & Oct-Nov \\
\hline 18 & Eria reticosa Wight & Epiphyte & EG & July-Aug \\
\hline 19 & Eulophia graminea Lindl. & Terrestrial & MD & Sept-Oct \\
\hline 20 & Flickingeria nodosa (Dalz.)Seidenf. & Epiphyte & MD & July-Sept \\
\hline 21 & Geodorum densiflorum (Lam.)Schltr. & Terrestrial & $\mathrm{DD}, \mathrm{MD}, \mathrm{SEG}$ & Aug-Sept \\
\hline 22 & Habinaria longocorniculata Graham & Terresrial & SEG,MD & Aug-Sept \\
\hline 23 & Habinaria longicornu Lindl. & Terresrial & MD & Aug-Sept \\
\hline 24 & Habinaria rariflora A.Rich & Terrestrial & EG,SEG & Aug-Sept \\
\hline 25 & Habinaria virusens & Terrestrial & Grass lands & Aug-Sept \\
\hline 26 & Liparis walkeriae Graham. & Terrestrial & EG & July-Aug \\
\hline 27 & Luisia birchea $\mathrm{Bl}$. & Epiphyte & EG & July-Aug \\
\hline 28 & Luisia zeylanica Lindl. & Epiphyte & EG & May- July \\
\hline 29 & Malaxis rheedii Sw. & Terrestrial & EG,SEG,MD & Aug-Sept \\
\hline 30 & Nervilia plicata (Andr.) Schltr. & Terrestrial & EG,SEG & Aug-Sept \\
\hline 31 & Oberonia brunoniana Wight. & Epiphyte & $\mathrm{EG}, \mathrm{SEG}$ & Sept-Oct \\
\hline 32 & Oberonia denticulate Wight. & Epiphyte & EG,SEG & July-oct \\
\hline 33 & Oberonia proudlockii King \& Prantl & Epiphyte & EG,SEG & May-Aug \\
\hline 34 & Oberonia santapaui Kapadia. & Epiphyte & EG & July-oct \\
\hline 35 & Papillanthe subulta (koeing) Garay & Epiphyte & EG & Mar-Apr \\
\hline 36 & Peristylus goodyeroids (D.Don.) Lindl. & Terrestrial & SED,MD & Feb-Mar \\
\hline 37 & Polystachya concreta (jacq.) Garay \& Sweet & Epiphyte & EG,Shola & July-Aug \\
\hline 38 & Srihookera latifolia & Epiphyte & EG,Shola & July-Aug \\
\hline 39 & Tropidia angulosa (Lindl.) Bl & Terrestrial & EG,SEG & Aug-Sept \\
\hline 40 & Vanda spathulata (L) Spreng. & Epiphyte & MD & June-Sept \\
\hline 41 & Vanda tessellata (Roxb.) Hook. ex G.Don. & Epiphyte & DD & Sept-Oct \\
\hline 42 & Zexuine longilabris (lindi.) Benth. ex Hook.f. & Terrestrial & Shola & May-Aug \\
\hline
\end{tabular}

EG - Ever Green, SEG - Semi Ever Green, MD - Moist Deciduous, DD - Dry Deciduous.

Among this habitats Epiphytic 52.38\% of Orchids contributed higher percentage followed by Terrestrial $42.86 \%$ and Lithophytic $4.76 \%$.(Table 2). Epiphytic Orchids are highly trophical and subtrophical in distributed.

Table 2. Habitat percentage.

\begin{tabular}{clc}
\hline S.No & \multicolumn{1}{c}{ Habitat } & \% of occurrence \\
\hline 1 & Epiphytic & 52.38 \\
2 & Lithophytic & 4.76 \\
3 & Terrestrial & 42.86 \\
\hline
\end{tabular}

\section{REFFERENCES}

Ali Mohammad Asadi, (2009). Floristic study of firozeh Watershed (North Khorasan Provice). Research Journal of Biological Sciences 6(10): 1092-1103

Gamble, J.S. (1935). Flora of the presidency of Madras. London. I-III.

Karuppasamy, S., G. Muthuraj Rajasekaran, (2009). Status of Orchids in Kolli hills of Eastern Ghates, Tamilnadu. EPTRI - ENVIS Newsletter, 15:3-5.

Mabberly , D.J. (1997). The plant book, Cambridge, Cambridge University prees, 507P. 